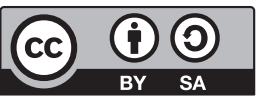

DOI 10.31261/IJREL.2019.5.1.03

\title{
Izabela Maleńczyk
}

Poland (ORCID: 0000-0002-8038-3667)

\section{Bartlomiej Gladysz}

Poland (ORCID: 0000-0003-0619-0194)

\section{Academic E-learning in Poland Results of a Diagnostic Survey}

\begin{abstract}
Academic e-learning is not a new phenomenon world-wide or in Poland. However, there are only a few publications examining academic e-learning in Poland from a wider perspective (i.e., country-wide, and not only from that of the specific course, faculty member, or university orientation), and none of them present complex analysis and diagnosis. The goal of this paper is to present an investigation of academic e-learning in Poland in both public and private universities. The sample of 139 universities was surveyed, and relations between variables - such as e-learning process characteristics and university characteristics - were analysed via hypotheses testing. Results of the survey may constitute a basis for comparison on a national and international level and offer strategic directions for university authorities.
\end{abstract}

K e y w ord s: academic e-learning, e-learning in Poland, diagnostic survey, dissemination of e-learning 


\section{Overview of Polish Academic E-learning}

Polish academicians have been enriching didactics with various forms of Internet and modern information technologies (IT). Intensive development of e-learning in Poland, which has caused significant changes in didactics at most universities, is historic. One of the main drivers for e-learning development was financial support of European Union (EU) funds. Projects that were financed and supported covered implementations of e-learning platforms, development of multimedia educational materials, online courses and training, and conferences and workshops promoting e-learning. The second important factor was a change in the law in 2007, which mandated applications of distance learning methods and techniques. Consequently, increasing research interest in e-learning in Poland has led to much published work on a national level, but mainly in Polish.

E-learning is practised in many Polish universities, and its forms are varied. A research gap exists in the area. Specifically, it is the absence of complex research and its dissemination vis-à-vis e-learning on the national (Polish) level. The goal of this paper is to present results of an assessment of Polish academic e-learning (in both public and private facilities). For this purpose, literature was reviewed, forming the basis for an empirical research. Examination of basic characteristics and descriptive statistics, as well as statistical hypotheses testing was undertaken. The tested hypotheses related to relationships between e-learning unit (and process) characteristics and university characteristics.

\section{Materials and Methods}

\section{State of the Art}

Primary analysis was conducted using a query "e-learning in Poland" in the Web of Science database in December 2018. All citation indexes in the Web of Science were included. Other databases were not included. Sixty-nine papers were found; after abstract screening, however, only seven papers in English (six short conference papers and one journal paper) were included in the analysis. Secondary analysis was prepared by querying databases of Polish journals (e-mentor, International Journal of Research in E-learning), conferences (eTEE, $D L C C, V U$ ), websites of centres and associations (PTNEI, SEA), and monographs widely disseminated in the e-learning environment. Numerous papers were found that were related to teaching of specific subjects, modules, courses, and degrees (e.g. Helenowska-Peschke, 2017). Such work was omitted, as it was not relevant to the scope of this study. There is absence of empiricism that has been undertaken 
using a complex approach to the dissemination of e-learning in Polish universities and the role of e-learning in didactics.

Those few publications (Table 1) address the following issues:

- quantitative fragmentary research, including satisfaction of stakeholders, efficiency and effectiveness of didactics, dissemination from university type perspective, and province perspective;

- qualitative research related to implementation cases studies and comparative analysis from faculty or university perspective, as well as practices of dedicated university-wide e-learning units.

Table 1.

Implementations of academic e-learning in Poland in the literature

\begin{tabular}{|c|c|c|}
\hline Type & Scope & Publication \\
\hline \multirow[t]{9}{*}{ Quantitative } & $\begin{array}{l}\text { Satisfaction of students } \\
\text { and/or employees }\end{array}$ & $\begin{array}{l}\text { Chomczyński, 2015; Dąbrowski, 2005; Kierzek } \\
\text { \& Tyburski, 2005; Szadziewska \& Kujawski, } \\
\text { 2017; Szadziewska \& Kujawski, 2016; } \\
\text { Woźniak-Zapór et al., } 2016\end{array}$ \\
\hline & Motivations & Rawa-Kochanowska, 2012; Wolski, 2011 \\
\hline & Efficiency of didactics & $\begin{array}{l}\text { Betlej, 2011; Klimas, 2015; Kwiatkowska, 2007; } \\
\text { Ordon \& Sołtysiak, } 2011\end{array}$ \\
\hline & Effectiveness of didactics & $\begin{array}{l}\text { Bizon, 2010; Bizon, 2012; Kula \& Plebańska, } \\
2011\end{array}$ \\
\hline & Quality of education & Zalewska, 2015 \\
\hline & Platforms & Redlarski \& Garnik, 2014 \\
\hline & University type-wide & Radkowska \& Radkowski, 2005 \\
\hline & Province-wide & Eisenbardt, 2007 \\
\hline & Country-wide & $\begin{array}{l}\text { Hołowiecki, 2014; Kraski, 2006; Kraski, 2007; } \\
\text { Kraski, 2008; Kraski, 2009; Maleńczyk, 2015; } \\
\text { Pleśniarska, } 2016\end{array}$ \\
\hline \multirow[t]{5}{*}{ Qualitative } & Academic e-learning unit & $\begin{array}{l}\text { Królikowski \& Susłow, 2010; Kula \& Plebańska, } \\
\text { 2012; Pańka, } 2012\end{array}$ \\
\hline & Faculty-wide & Grzeszczyk, 2010 \\
\hline & University-wide & $\begin{array}{l}\text { Binda \& Stofkova, 2017a; Binda \& Stofkova, } \\
\text { 2017b; Lenkiewicz et al., 2010; Paliwoda- } \\
\text { Pekosz \& Stal, 2015; Pokojski et al., 2011; } \\
\text { Rutkowski et al., } 2008\end{array}$ \\
\hline & $\begin{array}{l}\text { Comparative } \\
\text { (university-wide) }\end{array}$ & $\begin{array}{l}\text { Gajewski \& Jarosińska, 2011; Jaworska et al., } \\
\text { 2018; Kisielnicki \& Nowacka, 2013; Zając, } 2005\end{array}$ \\
\hline & Country-wide & Turula, 2015 \\
\hline
\end{tabular}




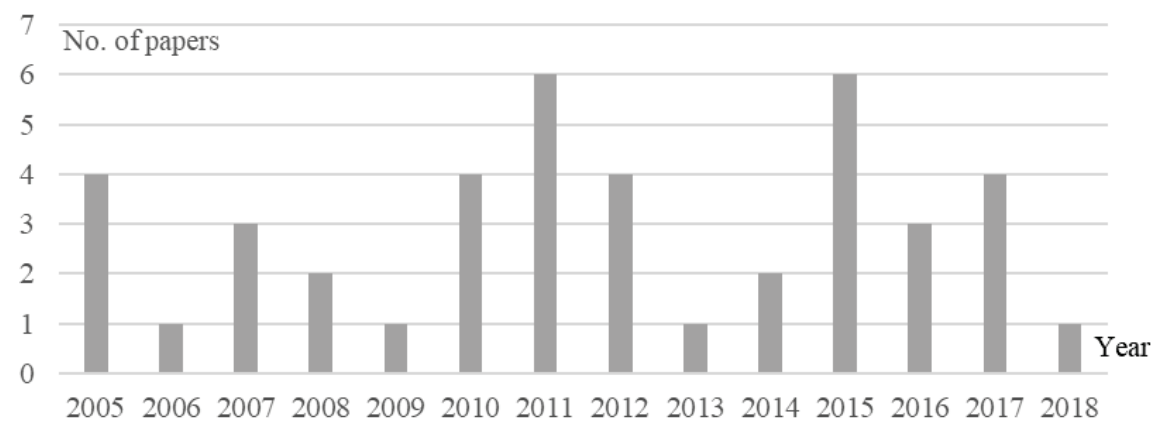

Figure 1. Analysed publications per year.

The momentums of Polish researchers' interest in the dissemination of their e-learning activities (not limited only to specific subjects, modules, courses, and degrees) were 2011 and 2015 (Figure 1). However, even then it was rather moderate, as maximum value was 6 papers in 2011. The historical yearly distribution of papers is probably a derivative of intensive implementations in that period and a number of EU-supported projects in Poland at that time. However, literature review per se (in any of its various forms, such as systematic literature review) is not the goal of this paper, nor the history and evolution of academic e-learning in Poland is. It may be the topic of separate and extended studies themselves. Therefore, the authors decided to limit the content of literature analysis section to pointing to the evidence of the existing research gap, which is the lack of holistic and up-to-date view of Polish academic e-learning. This gap determined goals discussed in the next section.

There was also the second gap identified, that is, the lack of up-to-date extended qualitative research on e-learning in Polish universities, including case studies, best practices, etc., to analyse contextual issues and phenomena of academic e-learning in Poland. For example, there was no follow-up of research on e-learning best practices conducted by Zając (2005). Turula (2014) provided qualitative discussion of Polish academic e-learning, its dominant prescriptive and controlbased character and small differentiation of forms. However, her research does not reflect on quantitative data proving qualitative analysis. The second gap is not addressed in the presented paper.

The most complex research found was a diagnosis of e-learning in public higher education (Pleśniarska, 2016) and analysis of the use of e-learning in Poland (Maleńczyk, 2015) (the only one country-wide paper in English). Both efforts, though, were not focused on academic e-learning centralised units, which is the subject of this article. Hołowiecki (2014) analysed the use of academic e-learning in Poland. This work is also limited. It is only partially of quantitative nature and covers only public universities. It answers research questions related to the presence (or its lack), reasons and processes of implementation and financing (or its 
lack), and basic features of e-learning platforms. Therefore, it does not provide the full picture of Polish academic e-learning. No existing work was found that presented a synthesis of country-wide research on academic e-learning. This issue has been addressed by Kraski (2006; 2007; 2008; 2009), but not comprehensively and it is outdated. All works discussed in this paragraph do not present statistical hypotheses testing for descriptions of characteristics and regularities in Polish academic e-learning.

With few English papers available, comparing specifics of academic e-learning in Poland with other countries is difficult. Additionally, it seemingly makes it impossible to place it in the wider context and disseminate results internationally. This paper contributes to the body of knowledge by approaching these twin weaknesses of existing relevant research.

\section{Research Procedure}

The general research goal was to diagnose the use of e-learning in Polish universities, both public and private ones. Detailed goals were as follows:

G1. Identification of academic units responsible for e-learning, with a specific focus on organisational, educational, and technological aspects.

G2. Identification of relationships between the use of e-learning and selected characteristics of universities (e.g., legal status, size).

G3. Identification of design of models of e-learning in universities.

G4. Identification of internal and external determinants of e-learning characteristics (strengths, weaknesses, potential, constraints) in the context of e-learning development.

G5. Identification of the needs of universities considering assessment of effectiveness of e-learning activities.

G6. Identification of key factors determining e-learning effectiveness from the perspective of stakeholders.

The research was multi-phase, using both quantitative and qualitative data, and focused on the following research questions:

Q1. What is the scale of dissemination of e-learning in Polish universities?

Q2. What organisational units are responsible for academic e-learning?

Q3. Are the size of university and number of students' user accounts correlated?

Q4. Are the size of university and number of exploited platforms correlated?

Q5. Are the size of university and existence of dedicated e-learning unit correlated?

Q6. Are the duration of the use of e-learning and the size of e-learning unit (number of employees) correlated?

Q7. Are the duration of the use of e-learning and the existence of dedicated e-learning unit correlated?

Q8. Are the existence of dedicated e-learning unit and the existence of full online studies correlated? 
Q9. Are the existence of dedicated e-learning unit and the use of e-learning quality assurance procedures correlated?

Q10. Are the number of user accounts and the size of e-learning resources (modules/courses) correlated?

Q11. What are the procedures of e-learning activities assessment applied by universities?

Q12. Is the need for the structured assessment and monitoring of academic e-learning units articulated?

Q13. Which factors are critical in the assessment of academic e-learning units' effectiveness?

Q3-Q10 were transformed into hypotheses for statistical testing for the population of all Polish universities, public and private ones.

Pragmatism guided the research. Mixed, complex (multi-phase) methods were used. The approach was heterogeneous. The main research was divided into four phases (Table 2).

Table 2.

Research procedure

\begin{tabular}{|c|c|c|}
\hline \multicolumn{2}{|c|}{ Phase } & Scope, methods, tools, techniques \\
\hline \multirow[t]{4}{*}{0} & 0.1 & State-of-the-art of e-learning in Polish universities \\
\hline & & $\begin{array}{l}\text { Analysis of existing data (secondary sources: Internet, reports, internal } \\
\text { documentation), electronic media monitoring (press clipping), phone interview }\end{array}$ \\
\hline & 0.2 & Verification and selection of academic e-learning units \\
\hline & 0.3 & Selection of experts from academic e-learning units \\
\hline \multirow[t]{3}{*}{1} & 1.1 & Collection of data on the use of e-learning in universities \\
\hline & & $\begin{array}{l}\text { Diagnostic survey; free-targeted interview; interview scenario with a list of } \\
\text { desired data }\end{array}$ \\
\hline & 1.2 & Detailing research area (boundaries and limitations of further research) \\
\hline \multirow[t]{5}{*}{2} & 2.1 & Gathering quantitative data on academic e-learning units \\
\hline & & Diagnostic survey; traditional or electronic survey; survey questionnaire \\
\hline & 2.2 & Design of e-learning models \\
\hline & 2.3 & Results analysis \\
\hline & 2.4 & Statistical verification hypotheses \\
\hline \multirow[t]{2}{*}{3} & 3.1 & Individual in-depth interviews \\
\hline & 3.2 & Results analysis and recommendations \\
\hline
\end{tabular}




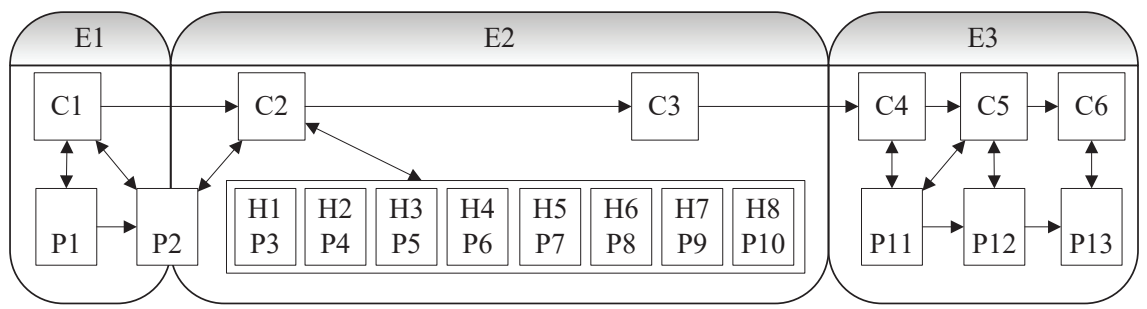

Figure 2. Research model.

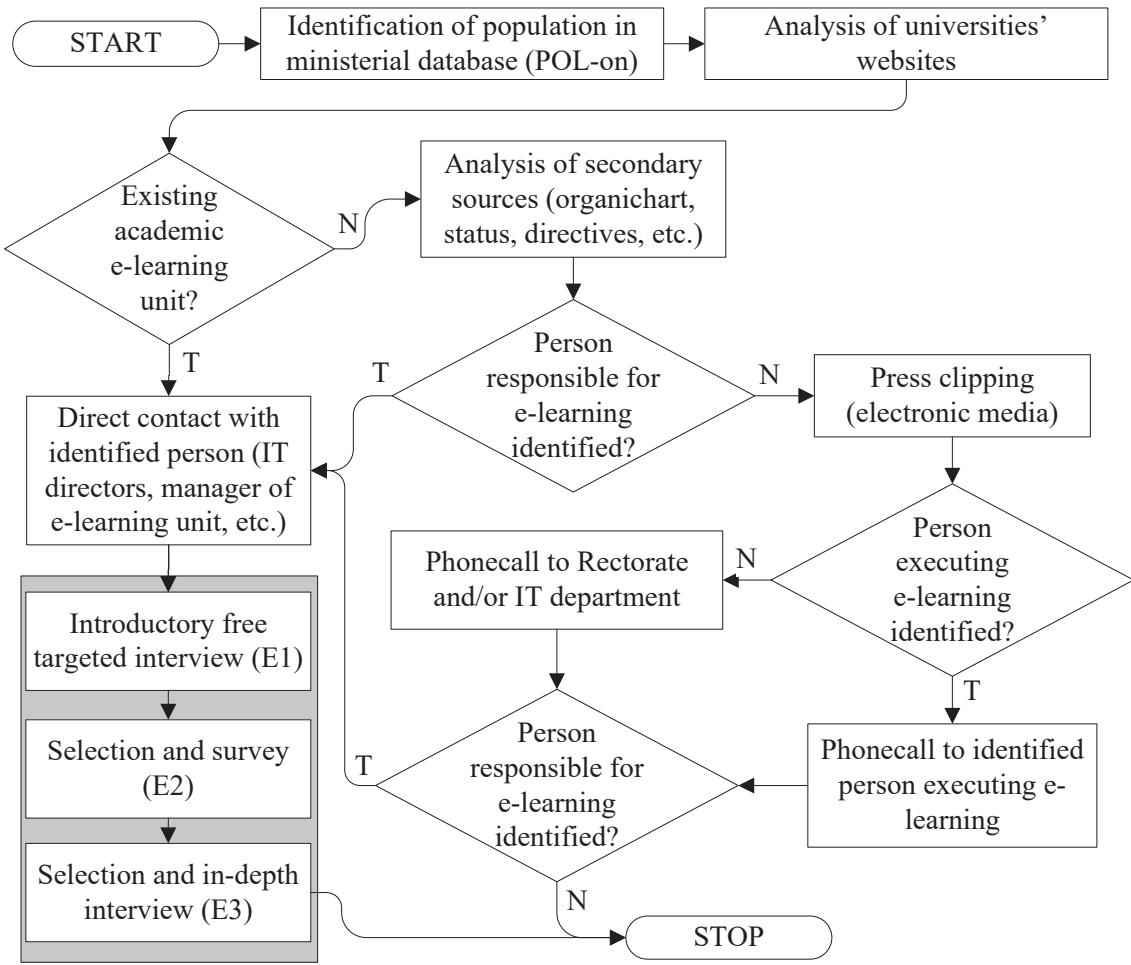

Figure 3. Research procedure.

Goals, questions, and hypotheses are presented on the research model (Figure 2). Pilot research was conducted to test research assumptions. Sampling was purposive. The entire population of Polish universities was approached based on data available from the government (Ministry of Science and Higher Education of the Republic of Poland, POLON database available at https://www.polon.nauka .gov.pl). The survey was (and also interviews, planned in further research, will be) directed to employees responsible for implementation or coordination of e-learning, decision makers, or influencers (directors/managers of units, specialists, pro-rectors and their deputies for e-learning). The research procedure is depicted on Figure 3. 
The questionnaire was anonymous and included 27 questions subdivided into four groups: particulars, characteristics, didactics, technology. Survey results were crosschecked with results of introductory (free targeted) interviews and secondary sources (see phase 0.1 and 1.1 in Table 2, see Figure 3). When feasible, chisquare analyses were applied to test the hypotheses. Chi-square analyses were not used when there was an insufficient number of categories. The U Mann-Whitney test was utilised to test differences between medians. The Shapiro-Wilk test was employed to test normality of a distributions. Pearson's r's and Spearman's rank correlation coefficients were calculated. When the study was undertaken, there were 410 Polish universities, including 141 public and 269 private ones.

Subsequent sections focus on phases 0-2 (see Table 2).

\section{Results}

\section{Introductory Free-targeted Interview}

A conceptual constraint was the interpretation of e-learning terminology. Therefore, terminology was carefully explained to interviewees concerning what e-learning meant in the research, i.e., educational process (learning and teaching), in which the knowledge is delivered using modern IT and Internet, specifically, and communication/interaction between all the stakeholders is fully or partially supported by electronic channels (synchronously and/or asynchronously). Another assumption for units selected for the investigation was that the unit is in the development or maturity stage of a lifecycle. Units implementing, testing, piloting, or terminating e-learning did not illustrate sufficient experience with e-learning, as those phases are changing too dynamically. Interviews showed high diversity of the form in which e-learning is practised in Polish universities (Table 3). A total of 256 introductory free-targeted interviews were conducted (Figure 3).

Another study problem was identification of relevant e-learning authorities. As such, this necessitated contacting multiple individuals within a university to obtain formal approval for research. Some individuals rejected participation in the study, owing to revelation of confidential data. Some private universities employed IT staff on a contractor basis, so contact with them was difficult (mainly via e-mail). Therefore, those universities without permanent IT staff were excluded from the study.

Another difficulty was an effect of the dynamics of private universities (i.e., liquidations, ownership changes, consolidations, and transformation of different types [e.g. new name]). This dynamism typically led to a change of strategy with regard to e-learning. 
Table 3.

Academic e-learning models in Poland concerning administration and IT

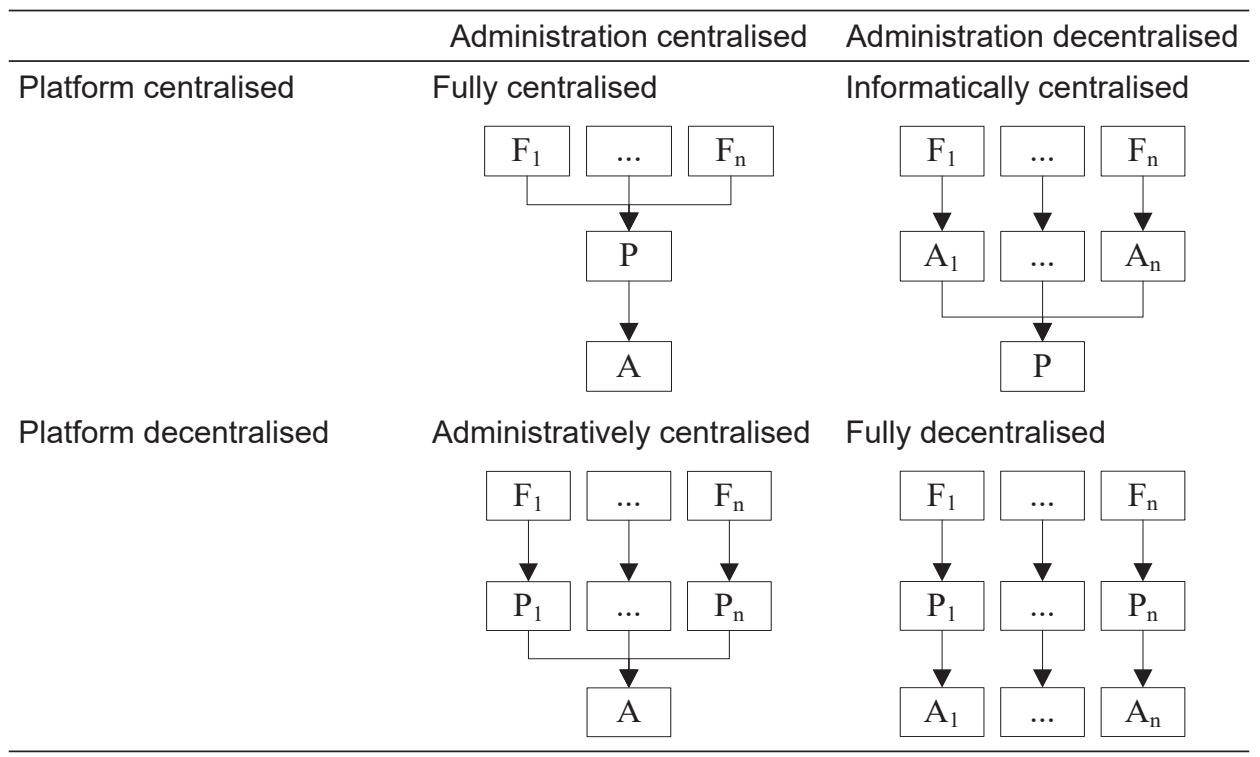

Note : A - administration; F - faculty; $\mathrm{P}$ - platform.

Grounding on interviews, fraction of universities declaring the use of e-learning and fraction of universities conforming research sample purpose were estimated, accordingly with indicators of the structure of a population. Public universities were grouped according to their teaching profile, as in ministerial registers (Table 4); private universities were categorised by province (Table 5).

Slightly more than $75 \%$ of all public universities used e-learning. All economic, pedagogical, nature, medical, maritime, military, state services, and physical education universities used e-learning. One university of technology and one general (academy) university revealed a lack of e-learning. E-learning was markedly less popular in professional (state higher professional schools) (ca. 70\% used it) and church and theology universities (above 50\%). Use of e-learning in art universities, however, was relatively unpopular (below 25\%).

Slightly more than $50 \%$ of private universities used e-learning. There were significant differences between provinces. All universities located in WarmiaMasuria, with over 70\% located in Lubelskie, Pomerania, and Greater Poland used e-learning. None located in Lubuskie used it. 
Table 4.

E-learning in Polish public universities

\begin{tabular}{|c|c|c|c|c|c|c|c|c|c|c|}
\hline \multirow[t]{2}{*}{ Profile* $^{*}$} & \multirow[t]{2}{*}{$\mathrm{N}$} & \multirow[t]{2}{*}{$U_{w}$} & \multirow[t]{2}{*}{$\mathrm{W}_{\mathrm{w}}$} & \multirow[t]{2}{*}{$U_{d}$} & \multirow[t]{2}{*}{$W_{d}$} & \multirow[t]{2}{*}{$W_{d}^{\prime}$} & \multirow[t]{2}{*}{$U_{b}$} & \multirow[t]{2}{*}{$\mathrm{W}_{\mathrm{z}}$} & \multicolumn{2}{|c|}{ Remarks ${ }^{* *}$} \\
\hline & & & & & & & & & a) & b) \\
\hline Art & 19 & 4 & 0.21 & 2 & 0.50 & 0.11 & 0 & 0.00 & $5 \mathrm{P}, 1 \mathrm{H}$ & $2 \mathrm{~L}$ \\
\hline Economy & 5 & 5 & 1.00 & 5 & 1.00 & 1.00 & 5 & 1.00 & - & - \\
\hline Medicine & 10 & 10 & 1.00 & 6 & 0.60 & 0.60 & 2 & 0.33 & - & $3 \mathrm{R}, 1 \mathrm{~K}$ \\
\hline Naval & 2 & 2 & 1.00 & 1 & 0.50 & 0.50 & 0 & 0.00 & - & $1 \mathrm{R}$ \\
\hline Pedagogy & 5 & 5 & 1.00 & 4 & 0.80 & 0.80 & 3 & 0.75 & - & $1 \mathrm{R}$ \\
\hline Nature & 6 & 6 & 1.00 & 2 & 0.33 & 0.33 & 2 & 1.00 & - & $4 \mathrm{R}$ \\
\hline State services & 2 & 2 & 1.00 & 2 & 1.00 & 1.00 & 1 & 0.50 & - & - \\
\hline Technology & 18 & 17 & 0.94 & 15 & 0.88 & 0.83 & 14 & 0.93 & - & $2 \mathrm{R}$ \\
\hline $\begin{array}{l}\text { General } \\
\text { (academies) }\end{array}$ & 18 & 17 & 0.94 & 15 & 0.88 & 0.83 & 11 & 0.73 & $1 \mathrm{H}$ & $1 \mathrm{R}, 1 \mathrm{~S}$ \\
\hline Military & 5 & 5 & 1.00 & 3 & 0.60 & 0.60 & 1 & 0.33 & - & $2 \mathrm{R}$ \\
\hline $\begin{array}{l}\text { Physical } \\
\text { education }\end{array}$ & 6 & 6 & 1.00 & 4 & 0.67 & 0.67 & 3 & 0.75 & - & $1 \mathrm{R}, 1 \mathrm{~T}$ \\
\hline Professional & 36 & 25 & 0.69 & 16 & 0.64 & 0.44 & 14 & 0.88 & $4 \mathrm{H}$ & $3 \mathrm{R}, 2 \mathrm{~T}, 4 \mathrm{~W}$ \\
\hline Others ${ }^{\star * *}$ & 9 & 5 & 0.56 & 3 & 0.60 & 0.33 & 3 & 1.00 & - & $2 \mathrm{R}$ \\
\hline SUM & 141 & 109 & 0.77 & 78 & 0.72 & 0.55 & 59 & 0.76 & - & - \\
\hline
\end{tabular}

N o te : * - profiles were taken from POLON database, **-a) declared lack of the use of e-learning; b) declared the use of e-learning, but not conformed with assumptions; $* * *$ - declared the use of e-learning, but not conformed with assumptions.

Legend:

$$
\begin{aligned}
& \mathrm{N}=\mathrm{U} \_\{\mathrm{W} \backslash\}+\mathrm{U} \_\{\mathrm{n}(\mathrm{P}, \mathrm{H}, \mathrm{D})\} \\
& \mathrm{U}_{-}\{\mathrm{d} \backslash\}=\mathrm{U}_{-}\{\mathrm{W} \backslash\}-(\mathrm{L}, \backslash \overline{\mathrm{K}}, \backslash \mathrm{R}, \mathrm{W}, \mathrm{T}, \mathrm{S}) \\
& \mathrm{W}{ }_{\mathrm{w}}=\mathrm{U} \mathrm{w} / \mathrm{N} \\
& \text { W_d }=\mathrm{U} \_\mathrm{d} / \mathrm{U} \_\mathrm{W} \\
& \text { W_d prime }=-U_{-}[\overline{\mathrm{d}} / \mathrm{N} \\
& \text { W_z }=\mathrm{U}_{-} \mathrm{b} / \mathrm{U} \_\mathrm{d}
\end{aligned}
$$

$H$ - declared former use of e-learning and lack of current use

$K$ - e-learning only for trainings (e.g. librarian, safety \& health, etc.)

$L-$ e-learning only in foreign languages education

$N$ - overall number of universities

$P$ - planning/initiating phase of e-learning

$R$ - fully decentralised e-learning

$T-$ test/pilot phase of e-learning

$S$ - closure phase of e-learning

$U_{n}$ - declared lack of the use of e-learning

$U_{b}-$ number of researched universities that conformed to research assumptions

$U_{d}$ - number of universities conformed with research assumptions

$U_{w}$ - declared the use of e-learning

$W$-implementation phase of e-learning

$W_{d}$-indicator of the use of e-learning in universities conformed to research assumptions

$W_{d}{ }^{\prime}$ - indicator of conformance with research assumption by universities that declared the use of e-learning

$W_{w}$ - indicator of the use of e-learning in universities

$W_{z}$ - return indicator (ratio of researched universities in those which conformed to research assumption) 
Table 5.

E-learning in Polish private universities

\begin{tabular}{lcccccccccc}
\hline \multicolumn{1}{c}{ Profile } & $\mathrm{N}$ & $\mathrm{U}_{\mathrm{w}}$ & $\mathrm{W}_{\mathrm{w}}$ & $\mathrm{U}_{\mathrm{d}}$ & $\mathrm{W}_{\mathrm{d}}$ & $\mathrm{W}_{\mathrm{d}} \mathrm{U}_{\mathrm{b}}$ & $\mathrm{W}_{\mathrm{z}}$ & \multicolumn{2}{c}{ Remarks $^{* *}$} \\
& & & & & & & & & $\mathrm{a})$ & $\mathrm{b})$ \\
\hline Lower Silesia & 21 & 13 & 0.62 & 11 & 0.85 & 0.52 & 5 & 0.45 & $1 \mathrm{P}, 1 \mathrm{H}$ & $1 \mathrm{~W}, 1 \mathrm{~T}$ \\
Kuyavia- & 15 & 10 & 0.67 & 10 & 1.00 & 0.67 & 6 & 0.60 & $1 \mathrm{P}, 1 \mathrm{H}$ & - \\
Pomerania & & & & & & & & & $1 \mathrm{H}$ & - \\
Lubelskie & 9 & 7 & 0.78 & 7 & 1.00 & 0.78 & 5 & 0.71 & $1 \mathrm{P}$ & - \\
Lubuskie & 4 & 0 & 0.00 & 0 & $\mathrm{n} / \mathrm{a}$ & 0.00 & 0 & $\mathrm{n} / \mathrm{a}$ & - & - \\
Lodzkie & 19 & 10 & 0.53 & 8 & 0.80 & 0.42 & 3 & 0.38 & $1 \mathrm{D}$ & $1 \mathrm{~W}, 1 \mathrm{~T}$ \\
Lesser Poland & 14 & 9 & 0.64 & 7 & 0.78 & 0.50 & 6 & 0.86 & $2 \mathrm{P}, 1 \mathrm{H}$ & $1 \mathrm{~T}$ \\
Mazovia & 73 & 34 & 0.47 & 28 & 0.82 & 0.38 & 22 & 0.79 & $4 \mathrm{P}, 6 \mathrm{H}, 4 \mathrm{D}$ & $2 \mathrm{~S}, 1 \mathrm{~T}, 3 \mathrm{~W}$ \\
Opolskie & 2 & 1 & 0.50 & 1 & 1.00 & 0.50 & 1 & 1.00 & $1 \mathrm{P}$ & - \\
Podkarpackie & 9 & 3 & 0.33 & 3 & 1.00 & 0.33 & 2 & 0.67 & $2 \mathrm{H}$ & $1 \mathrm{~W}$ \\
Podlasie & 12 & 6 & 0.50 & 6 & 1.00 & 0.50 & 3 & 0.50 & $1 \mathrm{H}, 1 \mathrm{D}$ & - \\
Pomerania & 18 & 13 & 0.72 & 9 & 0.69 & 0.50 & 7 & 0.78 & $1 \mathrm{H}$ & $1 \mathrm{R}, 2 \mathrm{~W}, 1 \mathrm{~T}$ \\
Silesia & 28 & 14 & 0.50 & 10 & 0.71 & 0.36 & 4 & 0.40 & $1 \mathrm{H}$ & $1 \mathrm{R}, 2 \mathrm{~W}, 1 \mathrm{~T}$ \\
Swietokrzyskie & 9 & 2 & 0.22 & 2 & 1.00 & 0.22 & 2 & 1.00 & $2 \mathrm{P}$ & - \\
Warmia-Masuria & 4 & 4 & 1.00 & 3 & 0.75 & 0.75 & 2 & 0.67 & - & $1 \mathrm{~K}$ \\
Greater Poland & 22 & 17 & 0.77 & 15 & 0.88 & 0.68 & 8 & 0.53 & $1 \mathrm{P}, 1 \mathrm{H}$ & $1 \mathrm{~S}, 1 \mathrm{~W}$ \\
West Pomerania & 10 & 4 & 0.40 & 4 & 1.00 & 0.40 & 4 & 1.00 & $2 \mathrm{H}, 1 \mathrm{D}$ & - \\
SUM & 269 & 147 & 0.55 & 124 & 0.84 & 0.46 & 80 & 0.65 & - & - \\
\hline
\end{tabular}

N o te : * - a) declared lack of the use of e-learning; b) declared the use of e-learning, but not conformed with assumptions.

L e g e nd: see Table 4.

A majority of Polish universities (62.4\%) declared that they implemented e-learning, but only $49 \%$ (of all universities) confirmed the assumptions for purposive sampling. There was a fraction of universities that closed $(5.6 \%)$ or were in the closure phase of (1\%) e-learning activities, mainly owing to usage of all external funds (EU projects), lack of teacher motivation, and insufficient skill and competence of academic staff (mainly full professors). One percent applied e-learning platforms only for particular courses (including language teaching). Twenty four universities (5.9\%) were in the implementation, testing, or pilot phase, and eighteen $(4.3 \%)$ were in the planning phase. Approximately five percent utilised a fully decentralised e-learning model (see Table 3), but only two of those were private and eighteen were public. Centralisation of e-learning was mainly driven by gaining experience and advancement in e-learning activities. 


\section{Survey}

Descriptive statistics. General descriptive statistics are presented in this section. The dataset is available upon request of the authors.

Most respondents were actively practising and managing e-learning with much professional experience (directors of e-learning units, platform administrators, specialists for e-learning) (Table 6). The survey was completed (and positively crosschecked with introductory free-targeted interviews and secondary sources, e.g. internal regulations) by 139 universities, 80 private and 59 public ones.

Table 6.

Structure of respondents

\begin{tabular}{lcc}
\hline \multicolumn{1}{c}{ Position } & Private universities & Public universities \\
\hline Director/manager of e-learning unit & $26.3 \%$ & $27.1 \%$ \\
Platform administrator & $23.8 \%$ & $28.8 \%$ \\
Specialists for e-learning & $22.5 \%$ & $16.9 \%$ \\
IT specialists & $12.5 \%$ & $8.5 \%$ \\
Other & $7.5 \%$ & $6.8 \%$ \\
Methodologist of e-learning & $3.8 \%$ & $3.4 \%$ \\
\hline
\end{tabular}

Public universities significantly more often $(49.2 \%)$ had a centre for e-learning in their structure than private universities did (26.3\%). Chi-square tests revealed a statistically significant correlation between type of university and type of e-learning academic unit in the university (Table 7). There was no significant correlation found between period of the use of e-learning and type of university $(p>0.05$, Table 8). Position of e-learning unit in the university structure was significantly correlated with the type of university $(p<0.05$, Table 9).

Table 7.

Structure of academic e-learning units

\begin{tabular}{lcc}
\hline \multicolumn{1}{c}{ Type of academic unit responsible for e-learning } & Private & Public \\
\hline Centre for e-learning & $26.3 \%$ & $49.2 \%$ \\
IT department & $38.8 \%$ & $27.1 \%$ \\
Lack & $27.5 \%$ & $16.9 \%$ \\
Other & $7.5 \%$ & $6.8 \%$ \\
$X^{2}=7.98$ & & \\
\hline
\end{tabular}


Table 8.

E-learning maturity in years

\begin{tabular}{|c|c|c|c|}
\hline & aturity in years & Private & Public \\
\hline 15 and more & & $8.8 \%$ & $8.5 \%$ \\
\hline $10-14$ & & $21.3 \%$ & $23.7 \%$ \\
\hline $6-9$ & & $23.8 \%$ & $33.9 \%$ \\
\hline $3-5$ & & $27.5 \%$ & $23.7 \%$ \\
\hline 2 and less & & $18.8 \%$ & $10.2 \%$ \\
\hline$x^{2}=3.18$ & $p=0.53$ & & \\
\hline
\end{tabular}

Table 9.

E-learning position in organisational structure

\begin{tabular}{|c|c|c|}
\hline Superior position & Private* & Public \\
\hline Rector's deputy & $13.8 \%$ & $49.2 \%$ \\
\hline Rector & $31.3 \%$ & $18.6 \%$ \\
\hline Chancellor & $25.0 \%$ & $23.7 \%$ \\
\hline Other & $21.3 \%$ & $8.5 \%$ \\
\hline Dean & $8.8 \%$ & $0.0 \%$ \\
\hline$x^{2}=25.56$ & & \\
\hline
\end{tabular}

No te : * The sum is not equal to $100 \%$ due to rounding.

Public universities significantly more often placed e-learning units under the rector's deputy supervision (49.2\%). Average employment in academic e-learning units was higher in public (4.42 FTE) than in private (2.95 FTE) universities. A Mann-Whitney $U$ test $(p<0.05)$ showed that the number of employees was dependent on the type of university (Table 10). No significant relationship between existence of advisory body for e-learning and the type of university was found, nor was the existence of methodologists of e-learning and the type of university (Table 11). E-learning activities were chiefly financed from central university budgets (both in public and private universities), and EU funds were no longer significant source of cashflow (Table 12).

Table 10.

E-learning unit employment

\begin{tabular}{lcc}
\hline & Private & Public \\
\hline $\begin{array}{l}\text { Average number of employees of e-learning unit } \\
Z=2.36\end{array}$ & 2.95 & 4.42 \\
\hline
\end{tabular}


Table 11.

Existence of advisory boards and methodologists of e-learning

\begin{tabular}{lllll}
\hline \multicolumn{3}{c}{ Experts supporting e-learning unit } & Private & Public \\
\hline Advisory board & $\mathrm{X}^{2}=25.56$ & $\mathrm{p}=0.02$ & $38.8 \%$ & $45.8 \%$ \\
Methodologist & $\mathrm{X}^{2}=25.56$ & $\mathrm{p}=0.02$ & $38.8 \%$ & $33.9 \%$ \\
\hline
\end{tabular}

Table 12.

Main sources of finance for e-learning

\begin{tabular}{lcc}
\hline \multicolumn{1}{c}{ Source of financing } & Private & Public \\
\hline Central university budget & $78.8 \%$ & $74.6 \%$ \\
Other & $7.5 \%$ & $15.3 \%$ \\
Self-financing & $13.8 \%$ & $5.1 \%$ \\
EU funds & $0.0 \%$ & $3.4 \%$ \\
Not applicable & $0.0 \%$ & $1.7 \%$ \\
\hline
\end{tabular}

There was a statistically significant relationship between the type of e-learning activity executed in the university and the type of university (i.e., online studies were more frequently in private universities [37.5\%], but other activities [e-learning courses and trainings] were not dependent on the type of university). There was a statistically significant relationship between the level of studies and the type of university. Public universities more frequently (44.1\%) applied e-learning on the tertiary level $(\mathrm{PhD})$ of higher education. For the bachelor level, a chisquare test could not be applied because of a nonsufficient sample. For masters and postgraduate education, there were no statistically significant relationships. The number of full-time students supported by e-learning showed a statistically significant relationship to the type of university. The part-time students, however, showed no statistically significant relationship. No statistically significant relationship was found between the form of classes and the type of university. A statistically significant relationship between the target groups of e-learning training and the type of university was found: public universities more frequently $(69.5 \%)$ applied e-learning for instructional courses for their staff (Table 14, Table 13).

There was no statistically significant relationship between the existence of standards for e-books development and the type of university $39.0 \%$ of public and $53.8 \%$ of private applied standards). There was a statistically significant relationship between the existence of e-learning evaluation procedures and the type of university. Public universities used evaluation procedures more frequently than private universities did (45.8\% versus $21.3 \%$ ) (Table 14$)$. 
Table 13.

Types of e-learning activities, levels and types of e-learning studies, forms of e-learning classes, target groups of e-learning trainings

\begin{tabular}{|c|c|c|c|}
\hline E-learning activity & Private & Public & Statistical significance \\
\hline Specific e-courses (subjects, modules, etc.) & $91.3 \%$ & $94.9 \%$ & $x^{2}=0.68 ; d f=1 ; p=0.41$ \\
\hline Specific e-trainings & $78.8 \%$ & $89.8 \%$ & $x^{2}=3.03 ; d f=1 ; p=0.08$ \\
\hline Online studies curricula & $37.5 \%$ & $11.9 \%$ & $x^{2}=11.42 ; d f=1 ; p=0.00$ \\
\hline Bachelor & $100.0 \%$ & $94.9 \%$ & $\mathrm{X}^{2}$ not applicable \\
\hline Master & $81.3 \%$ & $81.4 \%$ & $x^{2}=0.00 ; d f=1 ; p=0.99$ \\
\hline Tertiary (PhD) & $6.3 \%$ & $44.1 \%$ & $x^{2}=28.03 ; d f=1 ; p=0.00$ \\
\hline Postgraduate / MBA & $66.3 \%$ & $52.5 \%$ & $x^{2}=2.69 ; d f=1 ; p=0.10$ \\
\hline Full-time & $72.5 \%$ & $94.9 \%$ & $X^{2}=11.57 ; d f=1 ; p=0.00$ \\
\hline Part-time & $98.8 \%$ & $93.2 \%$ & $X^{2}$ not applicable \\
\hline Lectures & $91.3 \%$ & $96.6 \%$ & $X^{2}$ not applicable \\
\hline Exercises & $91.3 \%$ & $91.5 \%$ & $X^{2}=0.00 ; d f=1 ; p=0.95$ \\
\hline Lectureships (language) & $52.5 \%$ & $61.0 \%$ & $X^{2}=1.00 ; d f=1 ; p=0.32$ \\
\hline Seminars & $42.5 \%$ & $52.5 \%$ & $x^{2}=1.38 ; d f=1 ; p=0.24$ \\
\hline Projects & $31.3 \%$ & $45.8 \%$ & $x^{2}=3.05 ; d f=1 ; p=0.08$ \\
\hline Laboratories & $33.8 \%$ & $37.3 \%$ & $X^{2}=0.19 ; d f=1 ; p=0.67$ \\
\hline Instruction students training & $60.0 \%$ & $74.6 \%$ & $x^{2}=3.22 ; d f=1 ; p=0.07$ \\
\hline Instruction staff trainings & $41.3 \%$ & $69.5 \%$ & $X^{2}=10.88 ; d f=1 ; p=0.00$ \\
\hline Additional students' training & $45.0 \%$ & $45.8 \%$ & $X^{2}=0.01 ; d f=1 ; p=0.93$ \\
\hline Open for individuals & $20.0 \%$ & $15.3 \%$ & $x^{2}=0.52 ; d f=1 ; p=0.47$ \\
\hline Tailored for organisation & $18.8 \%$ & $15.3 \%$ & $x^{2}=0.30 ; d f=1 ; p=0.59$ \\
\hline Others & $6.3 \%$ & $5.1 \%$ & $X^{2}$ not applicable \\
\hline
\end{tabular}

Table 14.

Quality assurance of e-learning didactics

\begin{tabular}{lccc}
\hline \multicolumn{1}{c}{ Position } & Private & Public & Statistical significance \\
\hline Standards for e-books development in place & $53.8 \%$ & $39.0 \%$ & $\mathrm{X}^{2}=2.97 ; \mathrm{df}=1 ; \mathrm{p}=0.08$ \\
Evaluation procedures in place & $21.3 \%$ & $45.8 \%$ & $\mathrm{X}^{2}=9.43 ; \mathrm{df}=1 ; \mathrm{p}=0.00$ \\
\hline
\end{tabular}

Interestingly, the fraction of universities that applied standards and procedures seemed to be relatively low, yet one conceivably would expect that such procedures should be in place in any university. Private universities more frequently $(67.5 \%$ versus $16.9 \%$ ) shared audiovisual files, while public universities more frequently (76.3\% versus $3.8 \%$ ) shared ePUB files. Webinars were more frequently used in private universities ( $27.5 \%$ versus $13.6 \%)$, but synchronous communication tools showed no statistically significant relationship to the type of university. 
Synchronous communication tools were used relatively rarely, and text chat was the most popular among them - but even it was not applied widely $(71.3 \%$ of private and $55.9 \%$ of public). A chi-square test manifested a relationship $\left(\chi^{2}=4.23, p=0.04\right)$ between integration of e-learning platform with information systems and the type of university. However, the number of universities that integrated e-learning platform with other information systems was relatively low (40.0\% of private and $57.6 \%$ of public) (Table 15).

Table 15.

Shared files, synchronous communication tools

\begin{tabular}{lccc}
\hline \multicolumn{1}{c}{ File type } & Private & Public & Statistical significance \\
\hline PDF & $97.5 \%$ & $93.2 \%$ & $\mathrm{X}^{2}$ not applicable \\
MS Office/ ODF & $85.0 \%$ & $86.4 \%$ & $\mathrm{X}^{2}=0.06 ; \mathrm{df}=1 ; \mathrm{p}=0.81$ \\
HTML/XHTML & $68.8 \%$ & $71.2 \%$ & $\mathrm{X}^{2}=0.10 ; \mathrm{df}=1 ; \mathrm{p}=0.76$ \\
Audiovisual & $67.5 \%$ & $16.9 \%$ & $\mathrm{X}^{2}=34.93 ; \mathrm{df}=1 ; \mathrm{p}=0.00$ \\
ePUB & $3.8 \%$ & $76.3 \%$ & $\mathrm{X}^{2}=79.00 \mathrm{df}=1 ; \mathrm{p}=0.00$ \\
LaTeX & $3.8 \%$ & $5.1 \%$ & $\mathrm{X}^{2}=0.15 ; \mathrm{df}=1 ; \mathrm{p}=0.70$ \\
\hline Text chat & $71,3 \%$ & $55.9 \%$ & $\mathrm{X}^{2}=3.49 ; \mathrm{df}=1 ; \mathrm{p}=0.06$ \\
Videoconference & $33.8 \%$ & $23.7 \%$ & $\mathrm{X}^{2}=1.64 ; \mathrm{df}=1 ; \mathrm{p}=0.20$ \\
None & $21.3 \%$ & $32.2 \%$ & $\mathrm{X}^{2}=2.12 ; \mathrm{df}=1 ; \mathrm{p}=0.15$ \\
VolP & $25.0 \%$ & $27.1 \%$ & $\mathrm{X}^{2}=0.08 ; \mathrm{df}=1 ; \mathrm{p}=0.78$ \\
Webinars & $27.5 \%$ & $13.6 \%$ & $\mathrm{X}^{2}=3.90 ; \mathrm{df}=1 ; \mathrm{p}=0.048$ \\
Multimedia table & $13.8 \%$ & $15.3 \%$ & $\mathrm{X}^{2}=0.06 ; \mathrm{df}=1 ; \mathrm{p}=0.80$ \\
Virtual class & $11.3 \%$ & $13.6 \%$ & $\mathrm{X}^{2}=0.17 ; \mathrm{df}=1 ; \mathrm{p}=0.68$ \\
\hline
\end{tabular}

N o te : Multiple choice was possible.

A Mann-Whitney U test revealed a statistically significant relationship between the type of university and the following variables:

- average number of resources available on an e-learning platform $(Z=2.08$, $\mathrm{p}=0.04$ ), which was significantly higher in public universities (570 versus 406 );

- average number of student accounts on e-learning platform $(Z=4.94, p=0.00)$, which was higher in public universities (7847 versus 1841);

- average number of teacher accounts on e-learning platform $(Z=3.38, p=0.00)$, which was higher in public universities (281 versus 88 ).

That was expected as public universities are generally bigger. 
Statistical verification of hypotheses. Eight hypotheses were formulated (H1-H8).

H1. The size of the university (number of students) and number of active student accounts on e-learning platform are correlated.

$\mathrm{H} 2$. The size of the university and the number of used e-learning platforms are correlated.

H3. The size of the university and the existence of e-learning dedicated unit are correlated.

H4. The time of e-learning implementation and the number of employees responsible for e-learning are correlated.

H5. The time of e-learning implementation and the existence of e-learning dedicated unit are correlated.

H6. The existence of an e-learning dedicated unit and the delivery of full online studies are correlated.

H7. The existence of an e-learning dedicated unit and application of quality assurance procedures for e-learning are correlated.

H8. The number of student and teacher accounts and the number of resources (subjects/courses) on e-learning platform are correlated.

Each hypothesis was formulated in three variants, i.e. for all researched Polish universities (x.1), for all researched private Polish universities (x.2), for all researched public Polish universities (x.3). Results of the hypothesis tests are presented in Table 16.

University sizes were categorised as follows:

(1) public universities:

- small: fewer than 10000 students, 31 universities;

- medium: from 10000 to 20000 students, 15 universities;

- large: from 20001 to 30000,8 universities;

- very large: over 30000 students, 5 universities;

(2) private universities:

- small: fewer than 2000 students, 57 universities;

- medium: from 2000 to 5000 students, 15 universities;

- large: from 5001 to 9000 students, 5 universities;

- very large: over 9000 students, 3 universities. 
Table 16.

Statistical verification of hypotheses

\begin{tabular}{|c|c|c|c|c|c|}
\hline \multicolumn{2}{|c|}{ Hypothesis } & \multirow{2}{*}{$\begin{array}{l}\text { Pearson's } r \text { / Spearman's rs / } X^{2} \\
r=0.73\end{array}$} & \multirow{2}{*}{$\begin{array}{l}\text { Correlation } \\
\text { Strong }\end{array}$} & \multirow{2}{*}{$\begin{array}{l}\text { Significant } \\
\text { difference }\end{array}$} & \multirow{2}{*}{$\begin{array}{c}\begin{array}{c}\text { Significance } \\
\text { level } p\end{array} \\
<0.05\end{array}$} \\
\hline $\mathrm{H} 1$ & 1.1 & & & & \\
\hline & 1.2 & 0.89 & Very strong & & $<0.05$ \\
\hline & 1.3 & 0.63 & Strong & & $<0.05$ \\
\hline \multirow[t]{3}{*}{$\mathrm{H} 2$} & 2.1 & $r s=0.21$ & Weak & & $<0.05$ \\
\hline & 2.2 & 0.11 & Very weak & & $>0.05$ \\
\hline & 2.3 & 0.30 & Weak & & $<0.05$ \\
\hline \multirow[t]{3}{*}{$\mathrm{H} 3$} & 3.1 & $r s=0.23$ & Weak & & $<0.05$ \\
\hline & 3.2 & 0.17 & Very weak & & $>0.05$ \\
\hline & 3.3 & 0.27 & Weak & & $<0.05$ \\
\hline \multirow[t]{3}{*}{$\mathrm{H} 4$} & 4.1 & $r s=0.43$ & Moderate & & $<0.05$ \\
\hline & 4.2 & 0.46 & Moderate & & $<0.05$ \\
\hline & 4.3 & 0.36 & Weak & & $<0.05$ \\
\hline \multirow[t]{3}{*}{$\mathrm{H} 5$} & 5.1 & $r s=0.19$ & Very weak & & $<0.05$ \\
\hline & 5.2 & 0.17 & Very weak & & $>0.05$ \\
\hline & 5.3 & 0.19 & Very weak & & $>0.05$ \\
\hline \multirow[t]{3}{*}{$\mathrm{H} 6$} & 6.1 & $x^{2}=0.05 ; d f=1$ & & No & $>0.05$ \\
\hline & 6.2 & $0.02 ; 1$ & & No & $>0.05$ \\
\hline & 6.3 & $0.04 ; 1$ & & No & $>0.05$ \\
\hline \multirow[t]{6}{*}{$\mathrm{H} 7$} & 7.1 & E-book standards $x^{2}=8.43 ; \mathrm{df}=1$ & & Yes & $<0.05$ \\
\hline & & Evaluation procedures $0.14 ; 1$ & & No & $>0.05$ \\
\hline & 7.2 & E-book standards $5.87 ; 1$ & & Yes & $<0.05$ \\
\hline & & Evaluation procedures $0.04 ; 1$ & & No & $>0.05$ \\
\hline & 7.3 & E-book standards $4.25 ; 1$ & & Yes & $<0.05$ \\
\hline & & Evaluation procedures $0.98 ; 1$ & & No & $>0.05$ \\
\hline \multirow[t]{5}{*}{$\mathrm{H} 8$} & 8.1 & Students accounts $r=0.34$ & Weak & & $<0.05$ \\
\hline & & Teachers accounts 0.42 & Moderate & & $<0.05$ \\
\hline & 8.2 & Students accounts 0.53 & Moderate & & $<0.05$ \\
\hline & & Teachers accounts 0.70 & Strong & & $<0.05$ \\
\hline & 8.3 & Students accounts 0.33 & Weak & & $<0.05$ \\
\hline
\end{tabular}

N o t e : Correlation strength was assumed as by Evans (1996), i.e., coefficient equal 0 then no correlation, $(0.00 ; 0.20)$ - very weak, $<0.20 ; 0.39)$ - weak, $<0.40 ; 0.59)$ - moderate, $<0.60 ; 0.79)$ - strong, $<0.80 ; 1.00)$ - very strong, 1 - perfect.

$\mathrm{n}=139$ (all), $\mathrm{n}=80$ (private), $\mathrm{n}=59$ (public). 


\section{Discussion and Conclusions}

There were several constraints while conducting the study interviews and survey. These were mainly related to organisational issues and difficulties with reaching trustable data. Therefore, survey results were verified and cross-checked with the results obtained from secondary sources and introductory free-targeted interviews.

The majority of universities used e-learning, but slightly less than $50 \%$ conformed to assumptions of purposive sampling: definition and scope of e-learning (in order to extract universities using e-learning only for training, but not for regular teaching), and the phase of the e-learning life cycle in the university (in order to eliminate units in implementation, testing, pilot, and closure phases).

Polish academic e-learning units were rather small (fewer than five employees [FTE] in public and fewer than three in private universities, on average). Also, advancement of e-learning tools varied significantly. On average, however, a relatively small group utilised a structured methodological support (advisory boards and/or methodologists) and quality assurance (e-books standards and/or evaluation procedures). This seems to be an area for potential improvement.

The size of the university and the number of active students' user accounts on e-learning platform were positively correlated for public, private, and total group of universities. The size of the university and the number utilising e-learning platforms were positively correlated for public and total group of universities, but for private universities it was not possible to confirm that relationship.

The size of the university and the existence of an e-learning dedicated unit were correlated for public and total group of universities, but for private universities it was not possible to confirm that relationship. E-learning maturity (measured in years of usage) and the number of employees (FTE) responsible for e-learning were positively correlated for public, private, and total group of universities. E-learning maturity and the existence of an e-learning dedicated unit showed a statistically significant relationship for the total group of universities, but no such conclusion could be made for public and private universities separately. The existence of an e-learning dedicated unit and conducting of full online studies were not statistically significantly related for public, private, or the total group of universities. Many universities (107) had an e-learning dedicated unit, but only less than 30\% were conducting full online studies. It is due to the fact that sub-groups of private and public were not numerous enough to prove dependency.

The existence of quality assurance for e-learning was analysed in two dimensions: (1) use of standards for e-books development, (2) use of evaluation procedures for e-learning didactics. The relationship between the first dimension and the existence of an e-learning dedicated unit was statistically significant for the public, private, and total group of universities. However, for the second 
dimension, this finding was not obtained. A positive correlation between the number of resources on an e-learning platform and the number of active teacher accounts was found for the public, private, and total group of universities. The same result was observed for the number of active students' user accounts, and the sum of teachers' and students' user accounts.

This study may offer practitioners, researchers, and educators a framework for undertaking similar research not only in higher education, but also in primary, junior high, and high schools. Therefore, comparative analysis on a national and regional level would be possible, thus permitting examination of differences and similarities concerning characteristics of economies, societies, demographics, and educational systems. The study results constitute a basis for further qualitative research: individual in-depth diagnostic interviews to find context, opinions, approaches, needs, dimensions, and tools employed for assessment of e-learning units' effectiveness, and design and verification of an integrated method of assessment of e-learning academic units, which possibly will be the subject of publishing in the future.

\section{Acknowledgements}

The results presented in this paper were obtained as a fulfillment in the $\mathrm{PhD}$ procedure of Izabela Maleńczyk opened at the Częstochowa University of Technology, Faculty of Management, under the supervision of prof. Stanisław Marciniak (Warsaw University of Technology, Faculty of Production Engineering) and assisting supervision of Bartłomiej Gładysz. Izabela Maleńczyk authored the methodology, designed research tools, conducted the research, collected and analysed data presented in this article, while Bartlomiej Gladysz supervised and revised the research. All the data presented in this text are excerpted from $\mathrm{PhD}$ thesis mentioned above.

\section{References}

Betlej, P. (2011). Skuteczność tradycyjnych i elektronicznych form kształcenia w zakresie przedmiotów ekonomicznych - wyniki badań [Efficiency of traditional and electronic forms of learning economy courses - research results]. e-mentor, 5(42), 45-50.

Binda, J. \& Stofkova, K. R. (2017a). Impact of information and communication technologies on improving the quality and effectiveness of the education process. In L. Gómez Chova, A. López Martínez, \& I. Candel Torres (Eds.), INTED Proceedings (pp. 6916-6923). Valencia: IATED. 
Binda, J. \& Stofkova, K. R. (2017b). Organizational and financial aspects of blended learning implementation at the university as a teaching supporting solution. In L. Gómez Chova, A. López Martínez, \& I. Candel Torres (Eds.), ICERI Proceedings (pp. 5904-5913). Sevilla: IATED.

Bizon, W. (2012). Efektywność wspomagania zajęć dydaktycznych e-learningiem w akademickim kształceniu ekonomicznym [Effectiveness of e-learning support for didactics of economy courses]. e-mentor, 1(43), 40-47.

Bizon, W. (2010). Trafność i rzetelność pomiarów poprzedzających badanie efektywności szkoleń e-learningowych [Accuracy and reliability of measurements preceding assessments of e-learning trainings' effectiveness]. e-mentor, 5(37), 23-28.

Chomczyński, P. (2015). Problemy nauczycieli zaangażowanych w kształcenie na odległość - wyniki terenowych badań jakościowych [Problems faced by teachers involved in e-learning - results of qualitative field study]. e-mentor, 3(60), 42-47.

Chwaleba, A. \& Poniński, M. (1998). Metrologia elektryczna [Electrical metrology]. Warszawa: WNT.

Dąbrowski, M. (2005). Formy wykorzystywania technologii informacyjno-komunikacyjnych w edukacji w opinii nauczycieli i studentów SGH [Forms of information and communication technologies exploitation in education from Warsaw School of Economics teachers' and students' perspective]. e-mentor, 1(8), 43-45.

Eisenbardt, M. (2007). Powszechność i zakres wykorzystania e-nauczania w szkolnictwie wyższym województwa śląskiego [Scope and spread of e-learning in higher education in Silesia]. In M. Dąbrowski \& M. Zając (Eds.), e-edukacja.net (pp. 197-205). Warszawa: FPiAKE.

Evans, J. D. (1996). Straightforward statistics for the behavioral sciences. Pacific Grove (CA): Brooks /ColePublishing.

Gajewski, R. \& Jarosińska, E. (2011). Technology Enhanced Learning w edukacji inżynierów [Technology Enhanced Learning for engineering education]. In M. Dąbrowski \& M. Zając (Eds.), Koncepcje i praktyka e-edukacji [Concepts and practice of e-education] (pp. 43-48). Warszawa: FPiAKE.

Grabowska, A. (2012). eUczelnia - eNauczanie na Politechnice Gdańskiej [eUniversity - eLearning in Gdansk University of Technology]. In M. Dąbrowski \& M. Zając (Eds.), E-learning: narzędzia i praktyka [E-learning: tools and practice] (pp. 186-193). Warszawa: FPiAKE.

Grzeszczyk, T. (2010). Rozwój zdalnego nauczania na Wydziale Zarządzania Politechniki Warszawskiej [Development of distance education in Warsaw University of Technology, Faculty of Management]. In M. Dąbrowski \& M. Zając (Eds.), E-learning w szkolnictwie wyższym potencjat $i$ wykorzystanie [E-learning in higher education - potential and exploitation] (pp. 239244). Warszawa: FPiAKE.

Helenowska-Peschke, M. (2017). Blended Learning Model for Computer Techniques for Students of Architecture. International Journal of Research in E-learning, 3(1), 62-75.

Hołowiecki, M. (2014). Wykorzystanie e-learningu jako formy kształcenia zdalnego na publicznych uczelniach wyższych w Polsce [The use of academic e-learning in Polish public universities]. Lingua ac communitas, 24, 185-206.

Jaworska, E., Hernik, J., \& Sirakoulis, K. (2018). Do we really need e-learning? Considerations based on the example of West Pomeranian University of Technology Szczecin, Poland and Technological Educational Institute of Thessaly, Greece. In L. Gómez Chova, A. López Martínez, \& I. Candel Torres (Eds.), INTED Proceedings (pp. 5315-5324). Valencia: IATED.

Kierzek, M. \& Tyburski, M. (2005). Badanie potrzeb i oczekiwań studentów i pracowników w kontekście rozwoju e-edukacji w Akademii Ekonomicznej w Poznaniu [Study of Academy of Economy in Poznan students' and teachers needs and expectations in the context of e-education development]. e-mentor, 1(8), 38-42. 
Kisielnicki, J. \& Nowacka, B. (2013). Modele nauczania e-learningowego i ich ocena. Analiza porównawcza na przykładzie PJWSTK i Uczelni Łazarskiego [E-learning models and their assessment. Comparative analysis of PJWSTK and Łazarski University]. In L. Banachowski (Eds.), Postepy e-edukacji [E-education development] (pp. 41-52). Warszawa: PJWSTK.

Klimas, P. (2015). Nowe media a skuteczność procesów kształcenia - perspektywa studentów Uniwersytetu Ekonomicznego w Katowicach [New media and efficiency of education perspective of University of Economy in Katowice]. Prace Naukowe UE w Katowicach [Journals of UEin Katowice], Uniwersytet w perspektywie ksztatcenia przez cate zycie [University in the perspective of long life learning], 74-84.

Kraski, M. (Ed.) (2006). Elektroniczna gospodarka w Polsce [Electronic economy in Poland]. Poznań: ILiM.

Kraski, M. (Ed.) (2007). Elektroniczna gospodarka w Polsce [Electronic economy in Poland]. Poznań: ILiM.

Kraski, M. (Ed.) (2008). Elektroniczna gospodarka w Polsce [Electronic economy in Poland]. Poznań: ILiM.

Kraski, M. (Ed.) (2009). Elektroniczna gospodarka w Polsce [Electronic economy in Poland]. Poznań: ILiM.

Królikowski, T. \& Susłow, W. (2010). Uczelniane Centrum Kształcenia na Odległość: studium przypadku [University Center of Distance Education - case study]. e-mentor, 5(37), 50-57.

Kula (Maleńczyk), I. \& Plebańska M. (2011). Ocena efektywności dydaktycznej e-nauczania w opinii studentów [Assessment of didactical effectiveness of e-learning from students' perspective]. In M. Dąbrowski \& M. Zając (Eds.), Koncepcje i praktyka e-edukacji [Concepts and practice of e-education] (pp. 92-98). Warszawa: FPiAKE.

Kula (Maleńczyk). I. \& Plebańska, M. (2012). Promocja e-learningu akademickiego - doświadczenia Ośrodka Kształcenia na Odległość Politechniki Warszawskiej [Promotion of academic e-learning - experiences of Center of Open and Distance Education, Warsaw University of Technology]. e-mentor, 3(45), 64-70.

Kuśmierek, Z. \& Korczyński, M. (2003). Measurement and Instrumentation - Why Needed in Engineering Education. In Proceeding of 14th Int. EAEEIE Conf. of Educational Innovations in EIE (pp. 1-5). Gdańsk: EIE.

Kwiatkowska, V. (2007). Wpływ formy wykładu na jego skuteczność dydaktyczną w kształceniu akademickim - wyniki badań własnych [Impact of lecture's from on didactical efficiency in higher education - results of study]. e-mentor, 1(18), 58-61.

Lenkiewicz, P., Drabik, A., \& Kotowski, R. (2010). Role of the e-learning platform in the integrated system of the management of the university. In EDULEARN Proceedings (pp. 6611-6615). Barcelona: IATED.

Maleńczyk, I. (2015). Analysis and level of use of e-learning in Poland. eLearning and Software for Education, 3, 54-59.

Marciniak, S. (1989). Zespolona metoda oceny efektywności przedsięwzięć techniczno-organizacyjnych [Integrated method of assessment of technical-organizational projects]. Warszawa: WPW.

Ordon, U. \& Sołtysiak, W. (2016). Skuteczność kształcenia akademickiego w formule e-learningu. Wybrane aspekty [Efficiency of academic e-learning. Selected aspects]. Edukacja-TechnikaInformatyka [Education-Technology-Informatics], 1(15), 39-43.

Pańka, M. (2012). Otwarta edukacja na Uniwersytecie Mikołaja Kopernika w Toruniu [Open education in Copernicus University in Toruń]. In M. Dąbrowski \& M. Zając (Eds.), E-learning: narzędzia i praktyka [E-learning: tools and practice] (pp. 161-166). Warszawa: FPiAKE.

Paliwoda-Pekosz, G. \& Stal, J. (2015). ICT in supporting content and language integrated learning: experience from Poland. Information Technology For Development, 21(3), 403-425. 
Pleśniarska, A. (2016). Wykorzystanie e-learningu w polskich uniwersytetach $w$ aspekcie rozwoju gospodarki opartej na wiedzy [E-learning in Polish universities in the context of knowledge economy]. Torun: Adam Marszałek.

Pokojski, W., Różański, J., \& Wicińska, J. (2011). Wdrażanie e-learningu w szkole wyższej na przykładzie Wszechnicy Polskiej - Szkoły Wyższej TWP [Implementation of e-learning on example of Wszechnica Polska University in Warsaw]. e-mentor, 4(41), 63-68.

Radkowska, J. \& Radkowski, K. (2005). Propozycja modelu wdrażania e-learningu w państwowych uczelniach zawodowych [Framework for e-learning implementation in state higher professional schools]. In M. Dąbrowski \& M. Zając (Eds.), E-learning w kształceniu akademickim [Academic e-learning] (pp. 176-184). Warszawa: FPiAKE.

Rawa-Kochanowska, A. (2012). Motywowanie w e-nauczaniu - z doświadczeń praktyka [Motivation in e-edition from practioner's perspective]. e-mentor, 4(46), 40-44.

Redlarski, K. \& Garnik, I. (2014). Zastosowanie systemów e-learningu w szkolnictwie wyższym [Applications of e-learning in higher education]. In B. A. Basińska \& I. Garnik (Eds.), Zarzqdzanie informatycznym środowiskiem pracy [Management of information work environment] (pp. 77-94). Gdańsk: WZiE PG.

Rutkowski, J., Moscinska, K., \& Klosowski, P. (2008). Blended education at large technical university located in highly urbanized metropolitan region. In IMSCI proceedings vol. 1 (pp. 160-165).

Szadziewska, A. \& Kujawski, J. (2017). Advantages and disadvantages of the blended-learning method used in the educational process at the faculty of management at the University of Gdansk, in the opinion of undergraduate students. In ICERI Proceedings (pp. 3938-3946). Seville: IATED.

Szadziewska, A. \& Kujawski, J. (2016). The usefulness of the blended-learning method in the opinion of full-time students of the Gdansk University. In EDULEARN Proceedings (pp. 1792-1801). Barcelona: IATED.

Turula, A. (2014). Kiedy dydaktyka akademicka jest nowoczesna: o potrzebie dywersyfikacji kształcenia na odległość [When Academic Teaching is Modern: the Need for Diversification of Distance Learning]. Kultura i Polityka, 15, 45-63.

Wolski, K. (2011). Motywacja wewnętrzna oraz chęć do korzystania z e-learningu - doniesienie $\mathrm{z}$ badań [External motivation and willingness to use e-learning - test message]. e-mentor, 1(38), 43-46.

Woźniak-Zapór, M., Grzyb, M., \& Rymarczyk, S. (2016). Dystrybutorzy wiedzy - badanie satysfakcji nauczycieli z wykorzystaniem narzędzi dostępnych w ramach platformy zdalnego nauczania [Knowledge distibutors - study of teachears' satisfaction applying tools from e-learning platform]. ZN WEiA PG [Journal of Faculty of Electrotechnics and Automation of Gdansk University of Technology], 48, 107-112.

Zając, M. (2005). Rozwiązania e-learningowe wybranych ośrodków akademickich - analiza dobrych praktyk. e-mentor, 5(12), 54-57.

Zalewska, E. (2015). Jakość kursów e-learning [Quality of e-learning courses]. In P. Wdowiński (Ed.), Nauczyciel akademicki wobec nowych wyzwan' edukacyjnych [Academic teacher in the context of new educational challenges] (pp. 105-113). Łódź: University of Łódź. 
Izabela Maleńczyk, Bartłomiej Gładysz

\title{
E-learning akademicki w Polsce - wyniki sondażu diagnostycznego
}

\author{
Streszczenie
}

E-learning akademicki nie jest zjawiskiem nowym na świecie, ani w Polsce. Jednakże publikacje podejmujące tematykę e-learningu w Polsce z szerszej perspektywy (tj. kraju, a nie jedynie przedmiotów, wydziałów czy uniwersytetów) są nieliczne. Żadna z tych publikacji nie prezentuje kompleksowej analizy i diagnozy. Celem niniejszego artykułu jest prezentacja diagnozy e-learningu akademickiego w Polsce zarówno dla publicznych, jak i prywatnych uczelni. Diagnozę przeprowadzono dla próby 139 uczelni. Przeprowadzono statystyczną weryfikację hipotez dla zależności pomiędzy zmiennymi opisującymi proces e-learningu a zmiennymi opisującymi uczelnię. Wyniki diagnozy mogą stanowić podstawę porównań zarówno na poziomie krajowym, jak i międzynarodowym, a także bazę dla wytyczania kierunków strategicznych przez władze uczelni.

Słow a kluc zow e: e-learning akademicki, e-learning w Polsce, sondaż diagnostyczny, upowszechnienie e-learningu

Izabela Maleńczyk, Bartłomiej Gładysz

\section{Академическое электронное обучение в Польше: результаты диагностического исследования}

\section{А н но т а и я}

Академическое электронное обучение не является новым явлением ни в мире, ни в Польше. Тем не менее, существует всего несколько публикаций, в которых рассматривается академическое электронное обучение в Польше с более широкой точки зрения (то есть, по всей стране, а не только в контексте конкретного курса, преподавателя или ориентации в университете), и ни в одной из них не представлен комплексный анализ и диагностика. Цель данной статьи - представить исследование академического электронного обучения в Польше как в государственных, так и в частных университетах. Выборка из 139 университетов была исследована, и отношения между переменными, такими как характеристики процесса электронного обучения и характеристики университета, были проанализированы с помощью проверки гипотез. Результаты опроса могут послужить основой для сравнения на национальном и международном уровнях и предложить стратегические направления для руководства университета.

К л ю ч е в ы е с л о в а: академическое электронное обучение, электронное обучение в Польше, диагностическое обследование, распространение электронного обучения 
Izabela Maleńczyk, Bartłomiej Gładysz

\section{E-learning académico en Polonia: resultados de una encuesta de diagnóstico}

\section{Resumen}

El e-learning académico no es un fenómeno nuevo ni en todo el mundo ni en Polonia. Sin embargo, solo hay unas pocas publicaciones que examinan el aprendizaje electrónico académico en Polonia desde una perspectiva más amplia (es decir, en todo el país y no solo desde el curso específico, el miembro del profesorado o la orientación universitaria) y ninguna de ellas presenta análisis y diagnósticos complejos. El objetivo de este trabajo es presentar una investigación del e-learning académico en Polonia en universidades públicas y privadas. Se encuestó a la muestra de 139 universidades y se analizaron las relaciones entre variables, como las características del proceso de aprendizaje electrónico y las características de la universidad, a través de pruebas de hipótesis. Los resultados de la encuesta pueden constituir una base para la comparación a nivel nacional e internacional y ofrecer direcciones estratégicas para las autoridades universitarias.

P a la bras c l a ve: e-learning académico, e-learning en Polonia, encuesta de diagnóstico, difusión del e-learning 